\title{
CHARTING
}

\section{WELFARE HISTORY}

\section{Three major new works}

Last year saw a resurgence of publications on New Zealand's welfare history. In October, 1998, the Historical Branch of the Department of Internal Affairs provided a forum for a discussion of some major new works in welfare history completed in the Branch or supported by its publishing assistance scheme. The seminar was also timed to coincide with the centenary of the Old-age Pensions Act.

Three speakers discussed their recent books, all published by Auckland University Press: David Thomson, whose A World Without Welfare: New Zealand's Colonial Experiment traces welfare before the welfare state; Margaret McClure, whose A Civilised Community: A History of Social Security in New Zealand 1898-1990 looks at changes in the provision of social security; and Bronwyn Dalley, whose Family Matters: Child Welfare in 20th-century New Zealand examines government services for children.

The discussion papers are reproduced here:

\section{A WORLD WITHOUT WELFARE $=$ AHEAD OF US, OR BEHIND?}

\section{David Thomson}

$\mathrm{B}$ UILDING HISTORIES is a key way for any group to make sense of itself - what it is, values or wishes to be, where it has come from or might yet go. Histories, inevitably, address contemporary concerns, and are revisited as current needs suggest, which is not to say that there is nothing more to the study of history than this.

Revision and reassessment are not usually driven by overt or deliberate present-centredness - the dialogue between past, present and future is more subtle, diffuse, nonlinear. And most professional historians in the Western tradition were familiar and comfortable with this, long before a strident postmodernist language came upon us.

The history of social welfare in societies such as our own is overripe for just such a rethink. From the late 19th century through to the 1970s the experience of citizens in 'developed' societies was of expanding public rather than familial or charitable protection against a widening variety of risks, coupled with rapidly rising real incomes, the whole enterprise being managed from the centre by a generally benign
State. It was an experience they liked on the whole, and a progressive history of growth and success, of King Dick and his old age pensions, Saint Micky and his social security scheme, was fashioned to sustain it. What went before was well left behind - Dickensian poverty, brutal workhouses, insulting charity, grinding overwork, struggling families, squalid cities, despair and insecurity. What had been achieved in our own century were irrevocable and mounting advances in equality and humanity, or the quality of life. Few experi- 
enced historians were so crude perhaps, and everyone still had their quibbles about what was or was not being done, but the broad interpretative frame was comfortably, even smugly linear and progressive.

The experiences of the last quarter century, whatever we think of them, do not fit this frame and so demand a thorough reassessment of it, and that is only just beginning.

By the 1990s, with a speed that bewildered most if not all of us, New Zealanders and others found themselves thinking and saying and doing things we had not long since thought impossible - charging for public services once free, clipping social security benefits, accepting wide and prolonged unemployment in our midst, living with immiserated neighbours, haranguing welfare dependants, pushing individuals to carry many more of life's risks, 'rolling back the state', and looking set to do a good deal more of each in the years ahead.

This should not - could not happen, according to our confident histories of state expansion and achievement. How can present experiences and historical understanding be reunited?

A number of historians, here and elsewhere, are now confronting this need, though we don't seem to find it easy: the power of the faith in inexorable forward movement (perhaps interrupted for a spell) remains strong, and most of those attracted to the history of social welfare have come and still come with 'Old Left' sympathies for the active, careing State. One line of attack focuses on the immediate: it was Margaret Thatcher or Ronald
Reagan or Roger Douglas who seduced us from the true path, and we will soon come back to our senses. That view does not take us far. Another more promising approach readdresses the whole of the present century, and notices the failures and the limitations of what was gained through state expansion into welfare areas. That still leaves the question of the longer sweep: we might flatten the progressive trajectory of the 20th century, but what is its relation to what went before?

This issue lies at the heart of my own work, which spreads across the last two or three centuries and New Zealand and Britain for the most part. A World Without Welfare: New Zealand's Colonial Experiment asks 'what was the 19th century background to our 20th century swings towards and now away from expansive public welfare'? It emphasises continuities - the most obvious are the persistence of barely-changing thoughts, emotions, speech patterns and key words concerning the merits and perils of public and private welfare. It emphasises the striking scale in earlier times of the counterparts to things we have claimed as unique advances of our own era: in early or mid-19th century rural England, to give an example, public pensions for those over age 65 were as or more generous in their context than would be state pensions in New Zealand before the 1960s. And it emphasises retreats as much as advances, or waves and cycles rather than linear progression: through several centuries AngloSaxon societies (and maybe others yet to be examined on these matters) have oscillated between greater public and private responsibility, with a full cycle of wax and wane taking more than a century to complete.

New Zealand occupies a peculiar position in this history. It was born in a Britain undergoing one of its periodic turns away from public generosity and towards individual and family duty. Because of this, public assistance through the poor law in particular was still fairly extensive, as a result of the later eighteenth century swing towards public relief, but it was a relief pattern now under mounting attack. The parliamentary debates and the periodical literature of the $1780 \mathrm{~s}$ and 1790s calling for national old age pension schemes, guaranteed minimum incomes and the like were now firmly replaced by the urgings of Malthus and Ricardo and Smiles, and by a poor law that was closed to the unemployed or underpaid, cutting allowances to others, harrying claimants and besmirching 'paupers' (our 'beneficiaries') at every turn.

The New Zealand settlers took from this a determination not to have public welfare in their new land. Such a thing would not be right, but seriously injurious, and in any case would not be needed. The colonists would be both chosen and self-selecting for their personal drive, hard work and respectability, and their commitment to 'self help' and 'getting on'. The new land, too, would offer opportunities for all to live in this desired way. There would be work for all who sought it, land for everyone to settle, space 
for families to thrive, and affluence sufficient to underpin all personal and familial responsibilities. Giving settlers an expectation of, let alone an entitlement to, public assistance would undermine the whole enterprise of building a 'Better Britain of the South Seas'. 'No poor law in New Zealand' became an abiding faith, and a central symbol of all they sought to leave behind.

Much did not work out as dreamed of course. But what is striking is how long and hard the settlers here clung to the vision of themselves as self-supporting individuals and families, who did not need and would not - must not - have the public safety net of pensions and allowances for the old, single mothers, orphans and the like which still characterised their homeland. Indeed, as the century drew towards its close, New Zealanders tightened their mid-century experiment. Laws on the responsibilities of relatives for the welfare of one another, for example, were extended and sharpened several times between the 1870s and World War One, and public expenditure on what we might loosely describe as 'health and welfare' fell relative to population and national income.

The 1890s did mark a crucial turning point, though not in quite the way we usually think. In those years the counterarguments for public welfare responsibility began to outweigh those for personal and familial obligations, but only just, and slowly, and reluctantly. It was peculiar circumstances, and in particular a sudden mushrooming of the numbers of the aged at the end of a long economic downturn, which brought New Zealanders to accept old age pensions for a poor yet respectable minority - and with that, to put into their laws for the first time an individual right to welfare assistance other than from family. It was an important shift, though one subject to considerable misgivings: what did this mean for the long attempt to fashion a new 'world without welfare'? Until the 1930s that breech with the 19th century was not pushed much wider, whereupon began a 40 -year surge in acceptance of public welfare in thought, word and action. And just as in earlier cycles, from the 1970s unease about the moral and material costs of it all the concern about 'character' and 'work incentives' and 'enterprise' grew to slow, halt and reverse the expansive thrust.

In each era there have been particular triggers for the lurch from one trajectory to another. But the historian also looks beyond the particular when such repetitions are evident. The central issue is, I suspect, that in all our thinking on public and private welfare responsibilities, and in our search for the appropriate balance between these, we are juggling mutually inconsistent goals: to encourage work and initiative yet protect those lacking these attributes, to force adults to take responsibility for themselves yet to protect their dependants (young and old) when they fail, to foster thrift yet shelter those who do not or cannot save, to punish and so discourage some behaviours (unmarried motherhood, deserting of families) yet stop short of inhumanity or poverty or a threat to social order. The inherent irreconcilability of aims, together with the fact that individuals and groups always adapt and reposition themselves for advantage whatever balance is struck between those aims, so rendering the circumstances of that balance obsolete, gives an inner dynamic to welfare history that is somewhat independent of external circumstances. And understanding that better must be a central goal of welfare historians now.

\section{Celebrating the 1940 Centennial}

\section{$=$ CALL FOR PAPERS}

In November 1999 the Stout Centre is holding a two-day seminar on the national celebrations marking New Zealand's first hundred years - including the 1939-40 Wellington Exhibition.

Abstracts of papers are invited, for 30-minute slots, and should be sent to:

J.M. Thomson, Stout Research Centre,

Victoria University of Wellington, PO Box 600, Wellington 